\title{
PARODIES OF RELIGIOUS HYMNS IN ŽEMAITIJAN CARNIVAL: SOCIAL INTERACTION AND CULTURAL EXPRESSION: EVERYDAY LIFE, FESTIVITIES AND RITUAL FORMS
}

\section{Lina Petrošienè}

Professor and senior research fellow at the Department of Philology, Faculty of Social Sciences and Humanities of Klaipeda University

e-mail: lina.petrosiene@ku.lt

\begin{abstract}
On costumed processions in Žemaitija on Shrove Tuesday, the 'beggars' were and are among the main characters, as attested by the mask's distribution area, the name 'Shrovetide beggars' being given to the whole band of masked people, and the relative abundance of the costumed "beggars" songs. This study examines some examples from the repertoire of Shrove Tuesday carnival songs in Žemaitija, parodies of religious hymns and folk songs, which the performers called hymns and which were performed in imitation of sacred singing. The present analysis identifies their features, origins and function at the Shrove Tuesday carnival.
\end{abstract}

Keywords: parodies of religious hymns, Carnival, Shrovetide, Žemaitija (Samogitia) 


\section{Introduction}

The Žemaitijan (Samogitian) Shrove Tuesday festival is the most documented and longest-lived traditional carnival in Lithuania. Carnival characters have a unique repertoire of musical and oral folklore, including songs of costumed 'beggars', 'Jews' and 'Gypsies', parodies of religious prayers and orations, and good luck wishes.

The article analyses a part of this repertoire, namely parodies of religious hymns and folk songs, which the performers called hymns and which were performed in imitation of sacred singing. The goal of this article is to reveal their features, origins and function at the Shrove Tuesday carnival. The object of the research does not include a large number of song samples. The article presents one of the most widespread and well-recorded bands of costumed 'beggars' singing songs and religious hymns as parodies at Shrovetide, songs like 'Aš užgimiau prasčiokèlis' ('I Came from Humble Origins') (33 examples), as well as a song/hymn parody 'Žalias kopūstèli' ('Green Cabbage’) (3 examples) and a contaminated song 'Kad aš èjau ị Šidlavą' ('When I was walking to Šidlava') ( 1 example). These statistics are conditional for several reasons. First of all, in presenting the research object, attention must be paid to the principles of the selection of materials. Considering a song to be the unity of a text (lyrics) and a melody, only fully recorded examples were analysed. Another important point is that, although the types of songs mentioned here are shared all over Lithuania, these songs are not sung at Shrove Tuesday carnivals in all regions. Finally, attention should be drawn to the genre's the improvisational nature, the values attached to it and the imperfect documentation, aspects related to both factors.

These songs and parodies of sacred hymns are the only examples in the repertoire of the Shrovetide carnival group that are related to religious music. These examples in the genre classification system of Lithuanian folk songs are assigned not to the calendrical songs, but to the didactic or humorous ones. The songs mentioned above also comply with the concept of calendrical songs. They used to be performed during certain festivals of a year or a festive season and were an integral part of the ritual.

Parodies of religious hymns as a separate object of Lithuanian musical folklore are almost entirely unexplored. They are mentioned in the analysis of other genres of folk songs: feasts, songs about drunkenness, humorous, etc. songs. Analysing Shrovetide songs in Žemaitija, the author has discussed the variants of a parody of religious hymns (Laurinavičiūtè-Petrošienè 2015, 2019), 
but a specific study of a parody of a religious genre in the Žemaitijan carnival has not been undertaken. Lithuanian folklore researchers pay more attention to the analysis of parodies of contemporary oral folklore (Anglickiene 2009, 2020; Anglickienė and Grigonytė 2016; Krikščiūnas 2008).

The word 'parody' is derived from the Greek parōidía, a 'song sung alongside another one' and has been known since ancient times. The pioneer of parody is considered to be the ancient Greek poet Hipponax. In literature, a parody is an imitation of the style and manner of a particular writer or school of writers (EB; VLEb). In music, a parody is a compositional technique, namely the use of a previously created piece of music in a new one. The term 'parody' has been used in music since 1587. The rules of parody are described in detail in $E l$ melopeo y maestro (1613) by the Italian musician Pedro (Pietro) Cerone (WDB). From the nineteenth century, the concept of parody is usually associated with comic, satirical pieces of music that use banal, deliberately obscene, or simply inappropriate musical and poetic texts (VLEa).

Parodies of religious forms in folklore are a well-known phenomenon of oral tradition. According to Peter Burke, who studied popular culture in early modern Europe (1500-1800) and the 'world of carnival', 'Any list of the genres of popular culture would be seriously incomplete if it omitted parody, notably the parody of religious forms. $<\ldots .>$ There were parodies of the Catechism, the Commandments, the Creed, the Litany, the Psalms, and, above all, the Our Father from the medieval Paternostre $d u$ vin to the political parodies of the Reformation and the wars of religion' (Burke 1994: 122). It may be added that research on European carnivals is incomplete without an analysis of religious parodies, which have been analysed in the studies of many authors (Burke 1994; Scribner 1978: 303-29; Bakhtin 1984; Monteiro 1964; Kuha 2012; Turkson 1995).

However, speaking of parodies of carnival 'mock battles', 'mock weddings', 'mock funerals' and religious forms, and basing himself on Claude Lévi-Strauss's insights, Burke doubts whether the adjective 'mock' is appropriately used and understood:

what seems to have been intended was not a mockery of religious or legal forms but the taking over of these forms for a new purpose'. [...] It looks as if the creators of popular culture took over ready-made forms from the official culture of the church and the law because for certain purposes they had 
no equally appropriate forms of their own, a procedure which illustrates the dependence of popular culture on the culture of the dominant minority and thus offers important evidence in favour of the "sinking" theory."

Religious forms could be easily intercepted because the audience knew their structure and sequence of content, and could easily focus on the message being conveyed (Burke 1994: 123). Specific, completely unrelated and different examples support this idea. Turkson, who researched the contrafactum and religious musical traditions of Africa, found that

The Roman Catholic missionaries gained a great deal of influence over their congregations by introducing popular songs which were used as a means of religious propaganda. It became the policy of the Church to replace the secular texts of popular songs with sacred ones, usually in the vernaculars. [...] The priests were aware of the fact that a well-known and catchy melody, particularly one that belongs to the culture, was likely to give wider currency to the religious version. (Turkson 1995: 165)

This example illustrates the shift in the opposite direction: how parodying popular culture serves to establish an official culture.

The parody of the religious hymn 'I Came From Humble Origins', which is explored in this article, and the circumstances of its creation show a different direction of cultural exchange and confirms the idea that parodies of religious forms were not always and in all cases considered mockery. The parody of this religious hymn or contrafactum was represented in literary work by the Bishop of Žemaitija Motiejus Valančius (see below). Both examples, the folk song-religious hymn parody 'I Came from Humble Origins' and 'A Song of Beggars', in Valančius' literary work, can be seen as supporting the 'sinking' theory. However, the use of a parody of a religious hymn at the Shrove Tuesday carnival is at least partly related to ridiculous situations and mockery.

In twentieth-century folklore, the parody was understood as 'borrowing' or 'adaptation'. In academic discourse it was considered plagiarism, and folklore of this genre was deemed to be inferior. According to Peter Narvaez, this is related to the theoretical doctrine of folklore science that prevailed at that time. Parodies have evolved not only from traditional sources but also from popular culture, so folklorists did not collect such material because it lacked 'purity'. This viewpoint was supported by the most influential twentieth-century folklorist, 
Alan Dundes. As he has pointed out, it has been the value judgement of many folklorists that the older the folklore the better it is, later folklore being less valuable (Narvaez 1977: 32). This attitude has been very pronounced in Lithuania since the beginning of the twentieth century. As a result, much of the later folklore material was not included in the archives and collections of folklore. Therefore, Lithuanian parodies of religious genres are poorly documented and remain almost unexplored.

\section{Begging and the Shrove Tuesday carnival 'beggars'}

In descriptions of the Shrove Tuesday carnival processions in Žemaitija from the nineteenth to the twentieth century, the bands of costumed characters were described in a rather similar manner:

If the morning (before midday) in the village was silent and mysterious, things would start happening in the afternoon, as the 'visitors' ('Jews', 'Ape', 'Heron', 'Goat', 'Horse', 'Beggars', 'Kanapinis' [Hempen Man, Hemper], 'Lašininis' [Porky, Fatso], 'Grim Reaper', 'Devil', 'Angel'), walking doorto-door, would start their activities, frequently accompanied by shouting, singing, speaking, laughing - with hubbub'. (Trinka 1935: 210)

In the costumed processions held in Žemaitija on Shrove Tuesday, the 'beggars' were among the main characters, as attested by the distribution area of the mask and its character, by the name 'Shrovetide beggars', given to the whole band of masked people and their procession, and the relative abundance of the costumed "beggars"' songs. There is no clergyman (priest) character in the

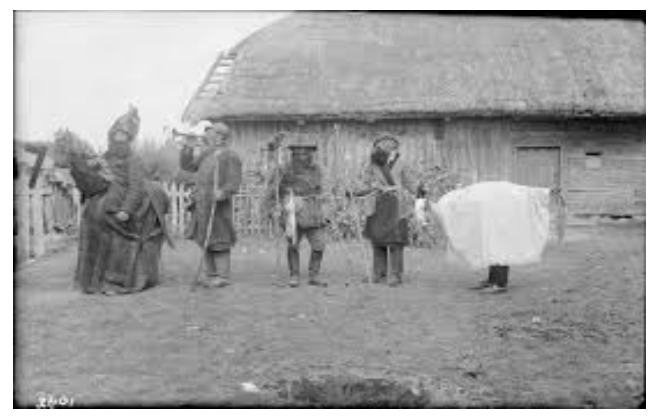

Fig. 1. Costumed Shrovetide characters in Žemaitija (1935) (LIMIS) 
Lithuanian Shrove Tuesday carnival. Dressing as the dead is not typical of Lithuanian calendrical holidays (Vaicekauskas 2005: 126), and 'funeral processions', in which a 'priest' usually participates, are also very rare. Parodies of religious hymns are performed by the whole group of disguised 'beggars'.

The genesis of the costumed beggars' parodies of songs and hymns at Shrove Tuesday, which became part of the calendrical folklore, is directly related to begging as a social phenomenon, mentioned as early as in written sources from the Middle Ages. As stipulated in the 1st Synod Decree of the Žemaitijan Bishop Jurgis Tiškevičius in 1636, permission to ask for alms at churches was only granted after the beggars had mastered the basics of the Catechism and provided they sang Catholic hymns when collecting alms. When travelling in the surrounding areas and stopping at farmsteads, beggars would also sing some hymns (Motuzas 2010: 18). The Žemaitijan Bishop Motiejus Valančius has giving us a picture of a physically healthy professional beggar, a gifted manager and an admirable hymn singer who lived in the mid-nineteenth century. This specific individual was a beggar, a pious hymn singer, who, thanks to his particular abilities, was able to earn substantial financial rewards, and sometimes even an important position and respect, in local village or township communities.

In Western Europe, travelling entertainers were frequently mistaken for beggars. Sometimes it was difficult to distinguish between professional singers and beggars who also made their living by singing and playing musical instruments. Some vagabond-entertainers were blind, while others just pretended to be blind. Therefore, the activities of vagabond-entertainers were first regulated as early as the sixteenth century. They were forbidden to wander far and wide or to beg without licences in the prescribed form (Burke 1994: 99).

The phenomenon of begging existed in reality, but the beggar as a representative of a social group whose external features and mode of behaviour were embodied in the figure of the 'beggar' was one of the main anthropomorphic characters of the Shrovetide carnival, mostly typical of Žemaitija. The negative features of the "beggars"' lifestyle and behaviour included greed, impudence, aggression, drunkenness and laziness, which occasionally were quite strongly pronounced. Therefore, at all times, attempts were made to control the lives of this particular segment of the marginal society and to provide them with somewhat more stable support. Both the positive and negative features of 
Parodies of Religious Hymns in Žemaitijan (Samogitian) Shrove Tuesday Carnival

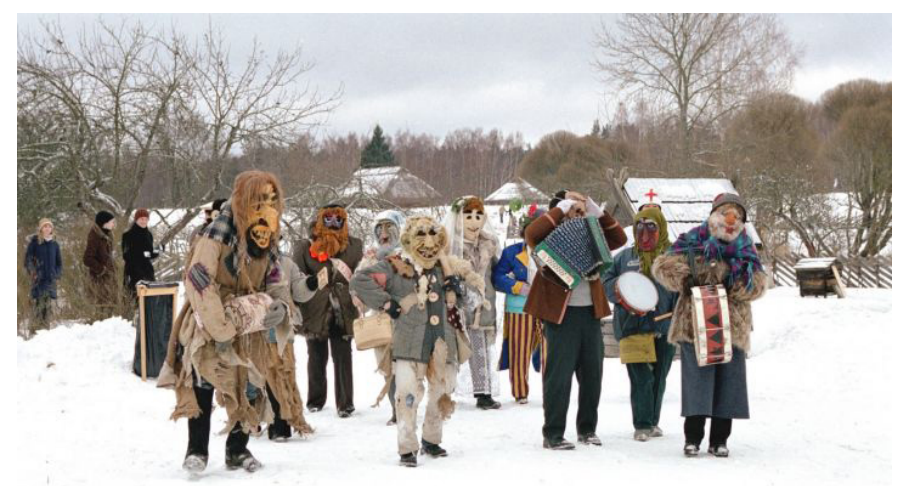

Fig. 2. Present-day character of Shrovetide 'beggars' (Alkas)

the actual lifestyle of the beggar were exploited in the role of the Shrovetide costumed 'beggar'. At all times, more frequent and easily observable negative reasons were given for why the priests of quite a few parishes criticized the costumed processions of Shrove Tuesdays and tried to ban them.

\section{Parodies of religious hymns at the Shrove Tuesday carnival}

In the late twentieth century, Žemaitijan presenters remembered the significant moment they entered the host's home:

Well, now I shall tell you how we walked around as 'Jews' and 'beggars' on Shrove Tuesday. [...] So we would walk, and sing songs and the like, and we had a diatonic-button accordion and played it. As we came in, we would sing the Shrovetide hymn, which was known by all. And if you did not know the hymn, the door would be closed on you and you would be asked to leave if you did not know the hymn. (ŽKT 2010: 42)

As the performer pointed out, that well-known hymn was 'Aš užgimiau prasčiuokieliu' ('I Came from Humble Origins'), which is one of the objects of this study.

The songs of the costumed beggars were called both songs and hymns by their presenters. Recalling the behaviour of the beggar procession inside her 


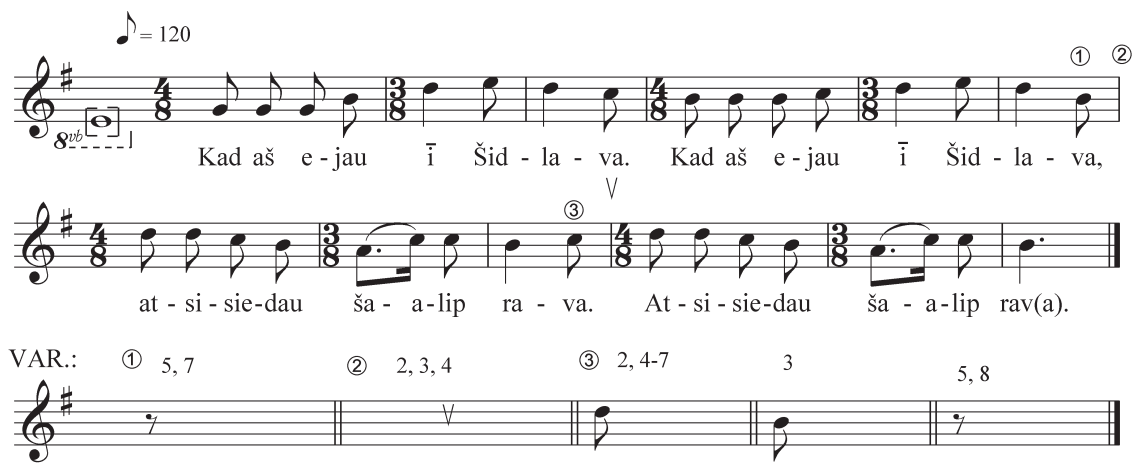

When I was walking to Šidlava,

I sat down at the ditch.

Fig. 3. When I was walking to Šidlava (ŽKT 2010: 10)

home, the presenter said: 'Well, and that song ('Kad aš èjau ị Šidlavą,' 'When I was walking to Šidlava'), we called it a Shrove Tuesday hymn. And all of us would get down on our knees, and no jokes, no tricks. [...] We sang so beautifully, like hymns are sung in church' (ŽKT 2010: 53).

The only sample of the song took the form of an obvious combination of the melody and lyric of another song/hymn parody, such as 'I Came from Humble Origins' (discussed below). From Stanza 6 of the song 'When I was walking to Šidlava', begging started for fat pork, typical of the versions of the song 'I Came from Humble Origins', promising a good place in heaven as a reward. In Aukštaitija, the songs and hymns of the group singing 'I Came from Humble Origins' were sung to the tune of 'When I was Walking to Šidlava'. This set of features, namely the circumstances and manner of performing the song indicated by the performer and the contamination of the poetic text, allow this song to be considered a parody of religious singing.

The main example of a parody of a religious hymn sung at the Žemaitijan Shrove Tuesday carnival is a group of songs called 'Aš užgimiau prasčiokèlis' ('I Came from Humble Origins'). One can assume that the parody of a Catholic hymn sung by costumed 'beggars' was a kind of a substitute for ritual calendrical songs that had been sung previously. The folk singing of Catholic hymns has been popular in Žemaitija from the time baptism was introduced there, when it filled a void in the sacred moments of calendrical festivals. The still 
Parodies of Religious Hymns in Žemaitijan (Samogitian) Shrove Tuesday Carnival

popular folk singing tradition in Žemaitija also penetrated into the folk songs of the rural Shrovetide festivals. The 'beggar' song/hymn 'I Came from Humble Origins' can be related to the so-called kantička hymns.

One of the oldest printed texts of the hymn 'I Came from Humble Origins' appeared in the mid-nineteenth century. In the story 'Palangos Juzè, ${ }^{2}$ published by Motiejus Valančius in 1863 (Valančius 1863b), this beggars' song, 'I Came from Humble Origins', appeared with information that 'the tune is of the [hymn] 'Vardan Tèvo galingiausio' ('In the Name of the Powerful Lord our God')':

'A Song of Beggars' (the tune as in 'In the Name of Powerful Lord our God')

I came from humble origins

And became a beggar.

I wander in the world praying,

Extolling my benefactors.

When people do not see me,

I enjoy good health.

All the joints are strong,

I could even do work.

As soon as I meet a man,

I immediately become lame.

I have a poor coarse homespun overcoat

And bow as low as I can.

Using two sticks to support myself,

I take a whip with myself

That I beat dogs with

When they attack me walking on the path.

I put on my 'nagines', ${ }^{3}$

And sometimes I obtain boots.

I have a nice cap,

Made of a piece of an old sheepskin.

I have a lot of beggar's sacks,

Five old ones and one new. 


\section{Lina Petrošienè}

The old ones are from sackcloth, And the new one is from tough leather.

My belts are also from leather, And rich men are envious of me. Copper buckles shine from afar Like a general's stars.

I now have a small cart, A good horse, and a pig. When I no longer want to walk, I can have a nice ride.

As a really strong guy I yell loud in the markets: 'Put at least a chunk of bread Into my leather sack'.

I get abundant alms And fill all my sacks. I feed my horse on bread And fatten up my pig.

As I come to some house Or get a slice of fat pork, I cook delicious dumpling soup Or sour potato soup.

And when I slaughter a pig, I make thick pease pudding And invite lots of beggars For that fat meal.

After the meal I can lie down, I don't care about ploughing or thrashing. I can sleep to my heart's content And nobody tries to wake me up.

Things are getting on well, 
Parodies of Religious Hymns in Žemaitijan (Samogitian) Shrove Tuesday Carnival

And girls like me.

I am going to get me a wife,

A red-cheeked beautiful Agatha.

Let great lords put on airs

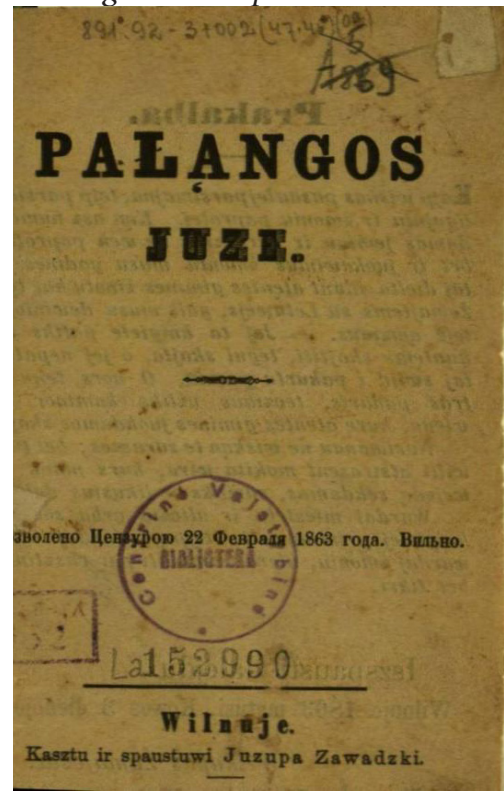

Fig. 4. 'Palangos Juzè' by Motiejus Valančius (Valančius 1863b)

Fig. 5. 'Kanticzkos' by Motiejus Valančius (Valančius 1863a)

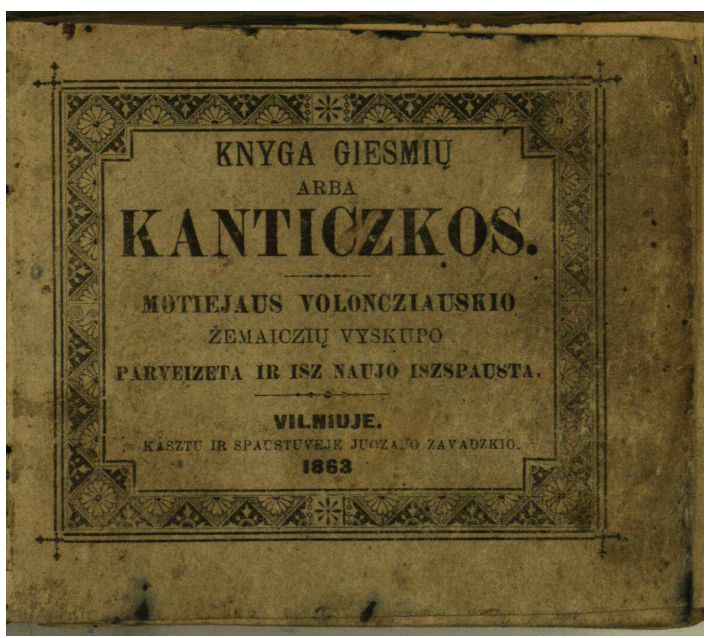


As well as people who have homes.

Even though I am more humble,

I am much happier than they. Amen. (Valančius 1863b).

'A Song of Beggars' is composed in the style of a contrafactum. The term 'contrafactum' is given to a vocal composition in which the original text is replaced by a new one, particularly a secular text by a sacred text, or vice versa (Turkson 1995: 165). In this case, the words of the religious hymn are replaced by secular ones, but it is sung to the tune of a particular religious hymn.

The performance of the song to the tune of the hymn 'In the Name of the Lord our God' in 'Palangos Juzë' by Valančius should be discussed separately. It is impossible to say exactly which melody he had in mind because there are no melodies in the book of hymns called 'Kanticzkos' that he published in 1863.

A variant of the same St. Francis hymn, 'Vardon Tievo to Praam囚eus' ('In the Name of God Praam冈eus') was published with a melody in the 'Gismiu lobynas' ('Thesaurus Lietuvanorum Hymnorum'), compiled by the priest Kazimieras Ambrozaitis (GL 1924: 405). Upon comparing one version of the melody of the hymn 'In the Name of God Praam冈eus' with the folk song/hymn parody 'I Came from Humble Origins', some similarities in the melodic line and the metrorhythmical structure (alternating triple and quadruple meter) were identified (see Figs. 6., 7. and 8.).
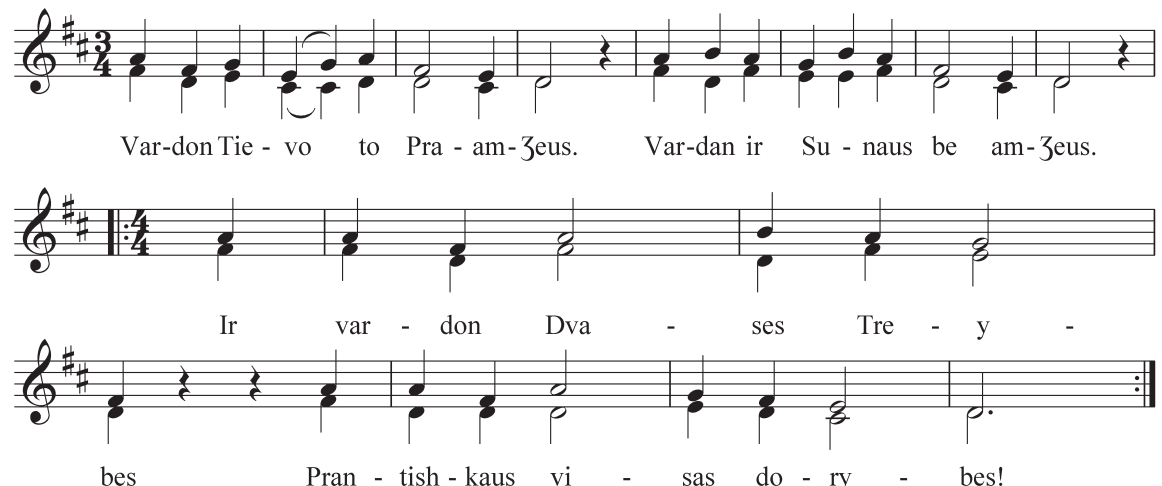

Fig. 6. In the Name of God Praam冈eus (GL 1924: 405) 

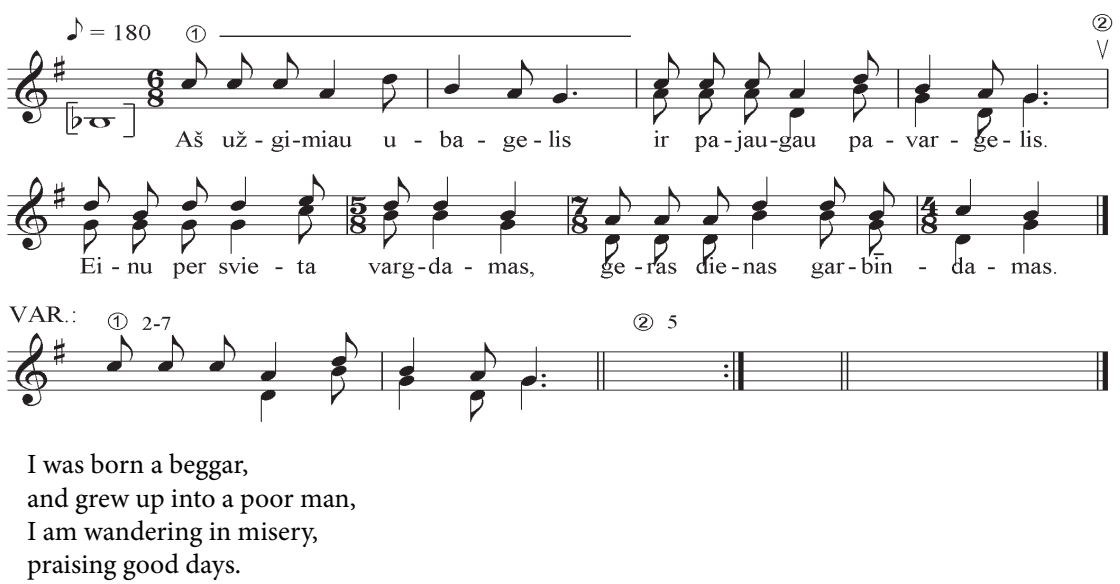

Fig. 7. I was born a beggar (ŽKKT 2010: 3)

From the content of the story, it can be seen that Juze from Palanga knew 'A Song of Beggars' very well and once sang it during the after-funeral meal, after he had lost patience with the bad singing of the beggars who had come to the meal. In that context, the performance of 'A Song of Beggars' was in no way related to Shrove Tuesday.

In the ethnographic material which was first systematically and purposefully collected in the first half of the 20th century, one can find reliable evidence that the song/hymn was performed by costumed characters on Shrove Tuesday: 'Shrove Tuesday 'beggars' were walking from door to door and singing funny songs, extolling hosts of the homesteads and asking for alms. They were funny creatures, and their 'hymns' were even funnier'. The 'beggars' sang:

As for the examples of the folk song group singing 'I Came from Humble Origins', recorded in the twentieth century, one can say that some texts are more developed, others less so, though they consist of similar motifs: the 'beggar's' introduction of himself, fake lameness, working tools, the declaration of possessed 'property', begging for alms, the organisation of the 'beggars' ball', the advantages of the status of a beggar, and the motifs of flirtation or an imaginary marriage. Many of the texts are slightly shorter and, after the beggar sings about his possessions, the text ends with a specific request: do not give me bread, or 
groats, or flour, just give me some fat pork, which the beggar promised would be repaid by a holy, good, warm place in the Heaven.

In some parodies, the melodic line is less developed and sometimes transformed into a recitation. Thus, in the song 'I grew up a beggar', the hymn of the 'beggars' and a parody of the žegnone folklore genre, consisting of a short saying
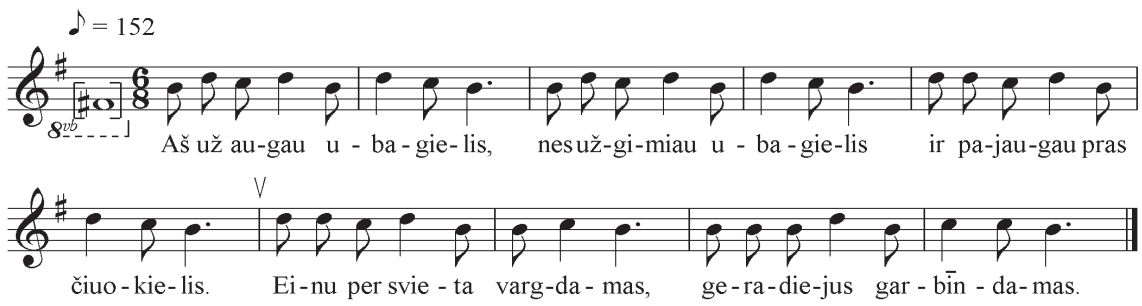

2,4 posmeliuose vyraujantis motyvas

3 posmelis rečituojamas

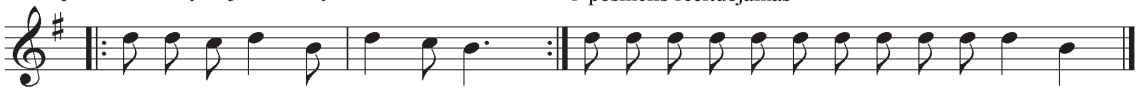

1. I grew up a beggar, as I was born a beggar, and was a commoner. I am wandering in misery, extolling my benefactors.

Fig. 8. I grew up a beggar (ŽKT 2010: 6)

The parody of prayer, intervening in the parody of the hymn, is performed as a recitative:

3. Amen, amen for those souls,

Where does the straw fall,

For one back, tail like awl.

Menski Papalenski, ${ }^{5}$

In the name of the tekšt ${ }^{6}{ }^{6}$ here through that tekšt,

Here's a girl's breast, here's a loaf of bread,

No one here, and no one left here. 
accompanying by crossing oneself, are intertwined. ${ }^{4}$ Upon singing a promise to secure one a place in heaven in exchange for a piece of fat bacon, the text describing one's crossing oneself follows. This combination of the genres is also evident in the melody: the stanzas of the hymn are performed in a primitive varying motif at an interval of the minor third, which, as soon as one starts to cross oneself, is recited as follows:

Two examples of the relationship between songs and hymn parodies can be clearly seen here, being instead unrelated to Shrove Tuesday (as in the already mentioned 'Palangos Juzë' of Valančius) and in the Shrove Tuesday environment.

Another parody, of the song or religious hymn called 'Žalias kopūstèli' ('Green Cabbage'), consists of a combination of a prayer (recitative) and a religious hymn (an imitation of the melody and style of the performance of sacred hymns). These genres and their mixing are well-known and characteristic forms of European carnival folklore (Burke 1994: 120-2). This parody of the hymn is quite well-known throughout Lithuania, but it is very poorly documented. The text of 'Green Cabbage' was collected without its melody by the famous twentieth-century local historian Jurgis Dovydaitis in Suvalkija (southern Lithuania).

The author of the article heard 'Green Cabbage' while singing with a folklore group of students from the Klaipeda Faculty of Music in 1987-1989, led by the folklorist Irena Nakiene. During the preparation of this article, three interviews were conducted with folklorists for information about this parody, and they sung three versions of it.

Nakiene remembers this parody of the hymn from her childhood, and she heard it at Shrovetide in Žemaitija around 1950. Later, working in cultural and educational institutions, she sang this song herself and taught it to ensemble participants and students. She also heard 'Green Cabbage' in the surroundings of Luokè, Telšiai and Šiauliai around the end of the twentieth century but did not write down. Nakienè said that 'Green Cabbage' is an improvisational piece, sung according to the situation and the need. In preparation for the Shrovetide procession, couplets singing humorously relevant content about local events or characters were created in advance. Sometimes they wrote them down on paper sheets, which, after singing, were thrown into the Shrovetide bonfire together with the burning stuffed effigy of More. These pieces seemed artistically worthless, and no one collected them. Sometimes they would mentioned 
- $=100$ Rubato quasi recitativo

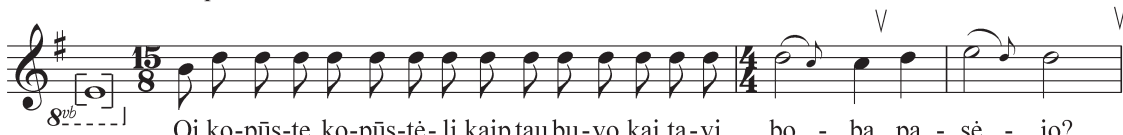

Oi ko-pūs-te ko-pūs-tè- li,kaip taubu-vo,kai ta-vi bo - ba pa - sé - jo?

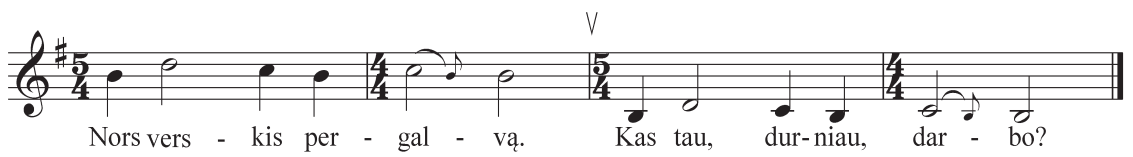

1. Oh, cabbage cabbage, how were you when a woman sowed you?

Chorus: Though you turn over your head.

What cares about you, fool!

2. Oh, cabbage cabbage, how were you when a woman sowed you and you sprouted?

Chorus...

9. Oh, cabbage cabbage, how were you when a woman sowed you / 2. and you sprouted / 3. and you grew up / 4. and you spread out the leaves / 5. and the woman cut you off / 6. and you were chopped up / 7. and you were fermented in the barrel / 8. and the woman ate you / 9. and the woman had diarrhoea?

Chorus...

Fig. 9. Oh, cabbage cabbage. Transcription by Lina Petrošienè

things that were unacceptable to the Soviet ideology of the time, so it was safer to destroy them (I. Nakiené, personal communication, 01-02-2021, Klaipèda).

The ethnomusicologist Rimantas Sliužinskas spoke about the 'Green Cabbage' in a very similar way. He heard this song in Aukštaitija (northeastern Lithuania) about 1979 and later, when he was working in Klaipeda (R. Sliužinskas, personal communication, 01-02-2021, Klaipeda). He sang the full version of the nine stanzas:

Parodies of religious hymns as a form of composition have the formula of a cumulative song consisting of two parts. The first part is performed as a recitative, imitating a prayer read by a 'priest'. In the second part, the chorus, the "parishioners" answer is sung with an unchanging text and a typical motif of the religious hymn's melody. Female voices sing the first line of the chorus, 'Though you turn over your head'. The second line, 'What cares about you, fool!' is sung by male voices.

Alvydas Vozgirdas, the leader of the folklore ensemble 'Kuršiu Ainiai', said that he sang this parody of the hymn 'Green cabbage' around 1990-1995. He learned the song in a folk group of students, later singing it himself in the 
folklore ensemble 'Kuršių Ainiai' led by Nakienè. The couplets were created before the Shrove Tuesday carnival, sometimes being improvised, but he never had a written text or melody. While studying folk music and later starting to conduct 'Kuršiu Ainiai', Vozgirdas collected the authentic folklore of Žemaitijan singers. During the interview, he sang two versions of 'Green Cabbage', though he could not say exactly what specific ritual of the Shrovetide celebration they were associated with. The Žemaitijan singers I interviewed could not say anything about it either (e.g., A. Vozgirdas, personal communication, 09-02-2021,

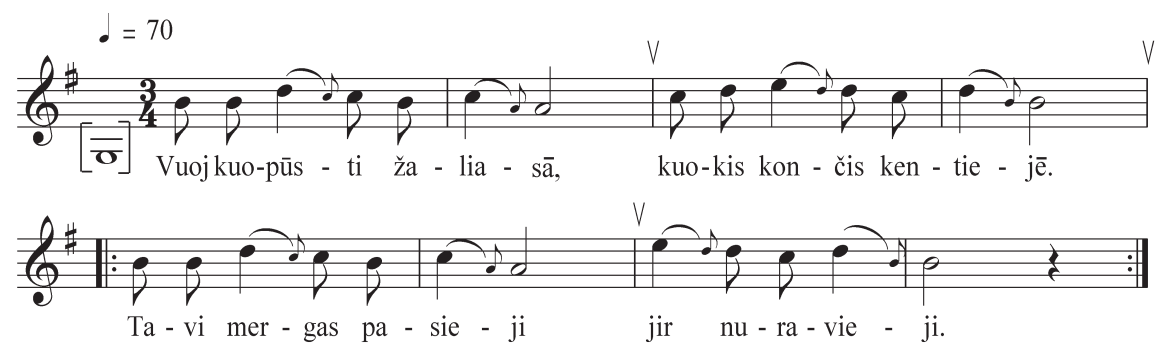

1. Oh, cabbage green,

What suffering you suffered.

The girls sowed you

And weeded you. $2 \times 2$

2. Oh, cabbage green,

What suffering you suffered.

The girls fermented you,

The women ate you. $2 \times 2$

Fig. 10. Oh, cabbage green. Transcription by L. Petrošienė 
Klaipeda). The versions of 'Green Cabbage' sung by Vozgirdas are close to the version 'Oh, cabbage cabbage' presented earlier (see Fig. 9.). These too are formula (cumulative) songs and parodies of religious hymns. However, one of them, 'Oh, cabbage green', is a formula song with a slightly different structure. It has no recitative, but the style of chanting is maintained:

\section{The features of the melodies}

From the musical perspective, the melodies sung by the costumed 'beggars' are rather late compositions. Their songs and hymns present a mixture of the elements of folk songs and Christian hymns. The songs of the costumed characters demonstrate the typical features of Žemaitijan melodies: a homophonic style, sung in a major scale, and specific incipits and cadences.

A distinctive feature of the Žemaitija region's musical dialect is their polyphonic character. From that viewpoint, Shrovetide carnival parodies of religious hymns are no different: almost all of them can and are performed in parts, the melody being accompanied in a traditional way (see Fig. 7).

The circumstances of the performance of Shrovetide songs predetermined their improvisational character: in a costumed procession, they are sung when communicating with people they have either visited or met on the way. Even if the model of the texts, especially that of the costumed 'beggars', seemed to have been established, in their live performance, different melodic and rhythmic variations were created.

The spontaneity of situations, the musical memory of the presenters, and the content of the texts of the hymn parodies were what accounted for their metro-rhythmical variety.

\section{Conclusions}

The first parody of a religious hymn to be recorded in the middle of the nineteenth century was described by the Bishop of Žemaitija, Motiejus Valančius, in his fictional work of literature. It is not possible to determine whether the parody of the religious hymn is his own work or whether only the oral folklore circulating among the folk people at that time is included in the literary work. Valančius' authority was very significant in the education of the masses of that time. It can be assumed that, thanks to his literary work, the parody of the religious hymn 'I came from humble origins' became well-known throughout 
Lithuania, acquiring folklore versions and a fixed place in the calendar holiday, the Shrove Tuesday carnival in Žemaitija, in the early twentieth century. These folk parodies of a religious hymn could easily have spread in Žemaitija because their melodies, although making a clear reference to religious music, are very close to the traditional musical folklore of this region. The humorous content of the hymn parodies caused no resentment among the priests and ecclesiastical authorities of that time.

'Green Cabbage', the parody of religious hymns and prayers presented on a calendrical holiday in the second half of the twentieth century, functioned rather obscurely and spontaneously. Its function and relationship with the rituals of the Shrove Tuesday carnival have not yet been established entirely clearly.

Given the evidence of written sources and the sociocultural context, it is clear that the origin of the songs examined here cannot be related solely to the Shrovetide environment. The 'beggar' songs and hymn parodies existed in two contexts. They have always been a syncretic genre, related both to the sociocultural and the calendrical festival environments. On the other hand, independent fields of their existence are also evident.

\section{Notes}

${ }^{1}$ The 'sinking' theory proves the idea that Great and Little Traditions have interactions between them. The lower classes, which cultivate the Little Tradition, borrow many things and adapt to their needs from Great Tradition of the upper classes. In fact, Burke sees some defects in the 'sinking' theory (Burke 1994: 58-64).

${ }^{2}$ The most famous work of literature by the nineteenth-century Lithuanian author, educator, historian, initiator of a temperance movement and Bishop of Žemaitija (1849-1875), Motiejus Valančius (1801-1875), is the story 'Palangos Juzè' (1863), which tells of a travelling village tailor, Juzė Viskanta, who comes back to his native home after a long tour of Žemaitija and Aukštaitija, and of the places he visited and their residents. Juzè tells his stories over thirteen evenings, and the literary work has thirteen chapters. Each chapter deals with an individual region of Lithuania and the everyday life and customs of its people. The book contains abundant ethnographic and folklore material. 'Palangos Juzè is a kind of the first textbook of Lithuania's geography and culture written as a work of fiction. Peripatetic tailors in Europe in the sixteenth to the eighteenth century were a widespread phenomenon, simultaneously creators and transmitters of popular culture (Burke 1994: 105).

${ }^{3}$ Sandals made of a single piece of leather. 


\section{Lina Petrošienè}

${ }^{4}$ Žegnõne also refers to making the sign of the cross (crossing oneself). Short saying-type parodies (e.g., a parody of the text accompanying the action of crossing oneself) are humorous sayings imitating serious texts with a religious or ritual content.

${ }^{5}$ Names in humorous form.

6 'Tekšt' is an onomatopoeic interjection, meaning a slight beating.

\section{Abbreviations}

Alkas - Olechnovičienè, Vida. Ar ruošiatės per Užgavėnes ị Rumšiškes? [Are You Preparing for Shrovetide in Rumšiškès?] Alkas.lt. Available at

https://alkas.lt/2012/02/14/ar-ruosiates-per-uzgavenes-i-rumsiskes/2012 m. vasario 14 d., last accessed on 20.11.2021.

EB - Parody. T. Editors of Encyclopaedia (2018, May 4). Encyclopaedia Britannica. Available at https://www.britannica.com/art/parody-literature, last accessed on 20.11.2021.

GL 1924 - Grynai Musishkai parashytu Gismiu Lobynas (Thesaurus Lietuvanorum Hymnorum: Gysmes su natums), Senovishkuju Vyta atstatytas ir naujums pilditas su Dideleis prydais gale, Kun. Kaz. Balandis-Zichkus-Ambrozajtys, Dorrisville, ILL.U.S.A.

LIMIS - Užgavėnès Dimgailių kaime. Pelikso Bugailiškio nuotrauka, 1935 [Shrovetide in the Village of Dimgailiai. Photo by Peliksas Bugailiškis, 1935]. Šiaulių „Aušros“ muziejus [Šiauliai "Aušra” Museum]. Lietuvos integrali muzieju informacine sistema [Lithuanian Integral Museum Information System]. Available at https:// www.limis.lt/detali-paieska/perziura/-/exhibit/preview/150000018420899?s_ id=1YmGiECyPMCToHzi\&s_ind=4\&valuable_type=EKSPONATAS , last accessed on 20.11.2021.

VLEa - Gudžinskaitè, Eglè. Parodija [Parody]. Visuotine lietuvių enciklopedija [Universal Lithuanian Encyclopedia]. Available at https://www.vle.lt/straipsnis/parodija-1/ last accessed on 27.01.2021.

VLEb - Koženiauskienè, Regina. Parodija [Parody]. Visuotine lietuviu enciklopedija [Universal Lithuanian Encyclopedia]. Available at https://www.vle.lt/straipsnis/ parodija/ , last accessed on 27.01.2021.

WDB - Cerone, Pietro 1613. El melopeo y maestro: Treatise on the Theory and Practice of Music. Naples, Italy: Juan Bautista Gargano and Lucrecio Nucci. World 
Parodies of Religious Hymns in Žemaitijan (Samogitian) Shrove Tuesday Carnival

Digital Library. Available at https://www.wdl.org/en/item/10633/ , last accessed on 20.11.2021.

ŽKT 2010 - Žemaičiu kalendorine tautosaka: Užgavenių dainos [Samogitian Calendrical Folklore: Shrovetide Songs]. L. Petrošienè, J. Bukantis (eds.). Klaipėda: Klaipėdos universiteto leidykla, 2010.

\section{References}

Anglickienè, Laima 2009. Šiurpès ir ju parodijos [Horror Stories and Their Parodies]. Tautosakos darbai [Folklore Studies] XXXVIII, pp. 15-29.

Anglickienė, Laima 2020. Parodies in Lithuanian Children's Folklore of the 21st Century: the World Turned Upside Down. In: Bankova, Petya, Janning, Michelle, Le Guennec, Aude, Tsaneva, Elya and Periklieva, Violeta (eds). Sociocultural Dimensions of Childhood. Sofia: Sofia: Prof. Marin Drinov Publishing House of Bulgarian Academy of Sciences, pp. 209-217.

Anglickienė, Laima \& Grigonyte, Kristina 2016. Pasakų parodijos ir perdirbiniai: ko jie mus moko? [Retold Tales and Parodies: What They Teach Us?]. Tradicija ir dabartis [Tradition and Contemporarity], Vol. 11, pp. 220-233. Available at: http://dx.doi.org/10.15181/td.v11i0.1448 last accessed on 12.01.2021.

Bakhtin, Mikhail 1984. Rabelais and His World. Bloomington: Indiana University Press.

Burke, Peter 1994. Popular Culture in Early Modern Europe. Revised reprint. Cambridge: Scolar Press.

Krikščiūnas, Povilas 2008. „Šią grandinę sudarè išproteję Gvatemalos pensininkai...“ [“This Chain Was Created by Crazy Guatemalan Pensioners...”]. Tautosakos darbai [Folklore Studies] XXXV, pp. 307-312.

Kuha, Miia 2012. A Parody of the Church Service in Seventeenth-Century Finland. Reconstructing Popular Religion on the Basis of Court Records. Frühneuzeit-Info, Vol. 23 (1-2), pp. 99-104.

Laurinavičiūtè-Petrošienè, Lina 2015. Žanro virsmas: Žemaitijos Užgavénių dainos [Transformation of the Genre: Samogitian Shrovetide Songs]. Klaipeda: Klaipedos universiteto leidykla.

Laurinavičiūtè-Petrošienè, Lina 2019. Shrovetide in Lithuania. Carnival Character Songs in a Sociocultural Context. Klaipeda: Klaipedos universiteto leidykla.

Monteiro, George 1964. Parodies of Scripture, Prayer, and Hymn. The Journal of American Folklore, Vol. 77 (303), pp. 45-52. Available at https://www.jstor.org/ stable/538018? seq=1, last accessed on 19.02.2021.

Motuzas, Alfonsas 2010. Švento Roko garbinimas Gruzdžiuose [St. Rock’s Worship in Gruzdžiai]. Žiemgala, Vol. 2. Available at http://www.ziemgala.lt/saugykla/ pdf/2_motuzas_3.pdf, last accessed on 20.02.2021. 
Narvaez, Peter 1977. The Folk Parodist. Canadian Folk Music Journal, Vol. 5, pp. 32-37. Available at https://cjtm.icaap.org/content/5/v5art8.html, last accessed on 19.02.2021.

Scribner, Bob 1978. Reformation, Carnival and the World Turned Upside-down. Social History, Vol. 3: 303-329. DOI: 10.1080/03071027808567430

Trinka, Vladas 1935. Užgavènių ir Pelenų dienos papročiai [Shrovetide and Ash Day Customs]. Gimtasai kraštas [Homeland], Vol. 5, pp. 210-212.

Turkson, Adolphus R. 1995. Contrafactum and Parodied Song Texts in Religious Music Traditions of Africa: A Search for the Ultimate Reality and Meaning of Worship. Ultimate Reality and Meaning, 18 (3), pp. 160-175. Available at https://www. utpjournals.press/doi/pdf/10.3138/uram.18.3.160, last accessed on 03.02.2021.

Vaicekauskas, Arūnas 2005. Lietuvių žiemos šventès [Lithuanian Winter Feasts]. Bendruomenès kalendorinio ciklo apeigos XIX a. pab. - XX a. pr. [Rites of the Community's Calendar Cycle in the Late 19th - Early 20th Centuries]. Kaunas: Vytauto Didžiojo universitetas.

Valančius, Motiejus 1863a. Knyga giesmių, arba Kanticzkos Motiejaus Voloncziauskio Žemaiczių vyskupo parveizeta ir isz naujo iszspausta kasztu ir spaustuveje Juozapo Zavadzkio [A Book of Hymns or Kanticzkos revised by Motiejus Voloncziauskis Bishop of Samogitia and reprinted with funds at the printing house of Juozapas Zavadzkis]. Epaveldas [E-heritage]. Available at https://www.epaveldas.lt/recordDescription/LNB/C1B0003195270, last accessed on 21.11.2021

Valančius, Motiejus 1863b. Palangos Juze [Juze from Palanga]. Wilniuje: Kasztu ir spaustuwi Juzapa Zawadzki.

Lina Petrošienè is a doctor of ethnology at Klaipeda University, where she is a professor and senior research fellow at the Philology Department of the Faculty of Social Sciences and Humanities. Her research explores ethnic music, folklore and cultural processes. Her work is focused on the ethnic music and customs of Lithuania Minor (Prussian Lithuania) and the Shrovetide in Lithuania and Europe. She is an expert of the Lithuanian Science Council and a former expert of the Lithuanian Culture Council. Since 2017, she has been a member of the Council for the Safeguarding of Ethnic Culture under the Parliament of the Republic of Lithuania. 